\title{
Contents, Volume 10 (1999)
}

Ahola, M. \& Ronkay, L.: Description of the larva of Cucullia mixta (Freyer) (Lepidoptera, Noctuidae .... 103-106

Buhl, P.N.: On a collection of Hymenoptera in Baltic amber, with the description of a new species of Pantolyta Förster, 1856 (Hymenoptera, Diapriidae $187-189$

Biström, O.: Hydrovatus wewalkai n.sp. described from Thailand (Coleoptera, Dytiscidae) 179-181

Fischer, M. \& Koponen, M.: A survey of Opiinae (Hymenoptera, Braconidae) of Finland, part 1 .................... 65-93

Fischer, M. \& Koponen, M.: A survey of Opiinae (Hymenoptera, Braconidae) of Finland, part 2 ............... 129-160

Gupta, S., Gupta, A. \& Meyer-Rochow, V.B.: Cuticular microstructures of abdominal tergites and sternites of Cloeon sp. (Epheme-roptera; Baetidae) during post-embryonic development

51-59

Heidemaa, M.: A new sawfly species Caliroa crypta sp. nov. from Northern Europe (Hymenoptera, Tenthredinidae) 183-186

Heidemaa, M. \& Viitasaari, M.: Taxonomy of the Empria hungarica species-group (Hymenoptera, Tenthredinidae) in Northern Europe 95-101

Junnilainen, J. \& Nupponen, K.: Buvatina iremella sp. n. (Lepidoptera: Oecophoridae) from the southern Ural Mountains 247-248

Jussila, R.: Additions to the revisions of the genus Stilpnus (Hymenoptera, Ichneumonidae) of the Palaearctic Region. I 107-112

Linnavuori, R.E. \& Modarres, M. : Studies on the Heteroptera of the Khorasan province in N.E. Iran. II. Cimicomorpha: Miridae 215-231

Mandelshtam, M.Ju.: Current Status of Ips amitinus Eichh. (Coleoptera, Scolytidae) in North-West Russia . 29-34

Nartshuk, E. P. : Grassflies of the subfamily Chloropinae (except the tribe Chloropini and the genus Meromyza) of Finland, Karelia and the Kola Peninsula (Diptera, Cyclorrhapha, Chloropidae .......................................... 7-28

Nupponen, K. \& Nupponen, T.: Scythris saarelai sp. n. from southem Spain and further records of Scythris mariannae Bengtsson, 1991 with a new synonym (Lepidoptera: Scythrididae) .................................................. 161-166

Park, K-T. \& Karsholt, O.: Revision of the genus Psoricoptera Stainton, 1854 (Lepidoptera, Gelechiidae), with the description of two new Asian species ................ 35-49

Pekkarinen, A. \& Gustafsson, B.: The Polistes species in northern Europe (Hymenoptera: Vespidae .... 191-197

Platia, G. \& Gudenzi, I.: New species and new or interesting records of click-beetles from Iran and Iraq (Coleoptera, Elateridae) ................................................. 117-125

Silfverberg, H.: Criocerinae from the Ethiopian Region (Coleoptera, Chrysomelidae) .............................. 209-213

Tanasijtshuk, V.N.: Leucopis formosana Hennig (Diptera, Chamaemyiidae) - synonymy, distribution, food links
Vikberg, V.: Lathroplex anthreni sp. n. (Hymenoptera, Ichneumonidae), a parasitoid on Anthrenus museorum (Linnaeus) in southern Finland 239-244

Vikberg, V. \& Itämies, J. : Buckthom (Hippophaë rhamnoides L., Elaeagnaceae), a new important food plant for the larva of Tenthredo vespa Retzius in Finland (Hymenoptera, Tenthredinidae) 201-208

\section{Brief report}

Huusela-Veistola, E. \& Vasarainen, A. 1999: Anoecia vagans (Koch) (Hemiptera, Aphididae) on roots of spring wheat in Finland.

Jussila, R. 1999: Ichneumonidae (Hymenoptera) new to Finland. V...................................................... 175-177

Koponen, M. 1999: Two species of Trachyusa Ruthe, 1854 (Hymenoptera, Braconidae, Alysiinae) in Finland ...... 199-200

Koponen, S. 1999: Three species of spiders (Araneae) new to the fauna of Finland from the southwestem archipela-

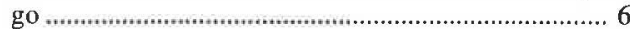

Linnavuori, R.E. \& Modarres, M. 1999: Studies on the Heteroptera of the Khorasan province in N.E. Iran. III. Cimicomorpha: Tingidae and Pentatomorpha: Berytidae .. 233-234

Silfverberg, H. 1999: Comments on some Estonian Coleoptera

50

Skartveit, J. 1999: Two species of Bibionidae (Diptera) new to the Finnish fauna ..................................... 115-116

Vuori, K.-M. 1999: Potamanthus luteus L. (Ephemeroptera, Ephemeridae) found for the first time in Finland: notes on the morphology and habitats of the nymphs

$171-174$

Vikberg, V. 1999: Crossocerus assimilis and Bethylus boops, two aculeate wasps new to the fauna of Finland (Hymenoptera, Crabronidae and Bethylidae) ....... 245-246

Wikström B. 1999: Teratological male genitalia among Coleophora species (Lepidoptera, Coleophoridae

$167-169$

\section{Short reports}

Haarto, A.: Syrphus admirandus Goeldin and Eristalinus aeneus (Scopoli) (Diptera, Syrphidae), Pseudoperichaeta nigrolineata (Walker), Cuphocera ruficornis Macquart, Aphria longilingua Rondani and Ramonda ringdahli (Villeneuve) (Diptera, Tachinidae) new to Finland . 1-2

Clayhills, T.: Atomaria lapponica Johnson, 1978 and A. strandi Johnson, 1967 (Coleoptera, Cryptophagidae) new to Finland

Clayhills, T.: Deletion of Ceutorrhynchus melanostictus (Marsham) (Coleoptera, Curculionidae) from the fauna of Finland 
Haarto, A.: New provincial record of the Diptera Cynomya mortuorum (Calliphoridae)

Iivarinen, R.: Lesteva punctata Erichson (Coleoptera, Staphylinidae) new to Finland ........................................ 2

Mannerkoski, I.: Deletion of Liophloeus lentus herbsti Gyllenhal (Coleoptera, Curculionidae) from the fauna of Finland

5

Mannerkoski, I.: New provincial records of the Coleoptera Silis ruficollis (Fabricius) (Cantharidae) and Dorytomus ictor (Herbst) (Curculionidae)

Mannerkoski, I.: Platysoma compressum (Herbst) (Coleoptera, Histeridae new to Finland

2

Mukkala, V-M.: New provincial record of the Coleoptera Tetratoma fungorum Fabricius (Tetratomidae) .......... 3

Nuorteva, J.: New provincial record of the Hymenoptera Pseudoclavellaria amerinae (Linnaeus)

Ranta, Y.: Faunistic rarities of the Coleoptera Aphodius subterraneus (Linnaeus) (Scarabaeidae) and Tetratoma fungorum Fabricius (Tetratomidae)

Ranta, Y.: New provincial records of the Hymenoptera Philanthus triangulum (Philanthidae) and Dasypoda hirtipes (Fabricius) (Melittidae) 3-4

Saarela, E.: Crunoecia irrorata (Curtis) (Trichoptera, Lepidostomatidae) new to Finland 2

Salokannnel, J.: Limnephilus hirsutus (Pictet) (Trichoptera, Limnephilidae) new to Finland 2

Turunen, H.: Hydroptila dampfi Ulmer, 1929 (Trichoptera, Hydroptilidae) new to Finland .................................. 2

Valtonen, P.: Faunistic rarities of the Strepsiptera Stylops melittae Kirby (Stylopidae), the Coleoptera Graphode- rus cinereus (Linnaeus) (Dytiscidae) and Oedemera croceicollis (Gyllenhal) (Oedemeridae) ........................... 4

Valtonen, P.: New provincial records of the Coleoptera $H y$ droporus semenowi Jakovlev and H. puberulus LeConte (Dytiscidae), Helophorus minutus Fabricius and Hydrochorus megaphallus van Berge Henegouwen (Hydrophilidae). 3

\section{Reviews}

Chapman, R.F. 1998: The Insects (Structure and Function). Cambridge University Press, Cambridge. Pp. 770. (V. Benno Meyer-Rochow) 113-114

Hansen, M. 1998: Hydraenidae (Coleoptera). World Catalogue of Insects. 1. - Apollo Books 168 pp. (Olof Biström) 63

Millar, J.G. and Haynes, K.F. 1998: Methods in Chemical Ecology. Chapman \& Hall, New York. Pp. 390. (V. Benno Meyer-Rochow) 61-62

Nielsen, O.F. 1998: De danske guldsmede Danmarks Dyreliv, Bind 8 (The Dragonflies of Denmark. Animal Life of Denmark, vol. 8) (Juhani Itämies). $127-128$

\section{Announcements}

Sveriges Entomologiska Förening 60,126

INDEX to genera and species, Volume 10 (1999) 249-269 CONTENTS, Volume 10 (1999) ........................... 271-272 